\title{
Upaya Meningkatkan Hasil Belajar Passing Bawah Bola Voli Dengan Pendekatan Pembelajaran Massed Practice
}

\author{
Ahmad Imistauma, Lalu Sapta Wijaya Kusuma, Ali Imran \\ Program Studi Pendidikan Olahraga dan Kesehatan, FIKKM Universitas Pendidikan Mandalika \\ Imistauma028@gmail.com
}

Received: Januari 2021; Accepted: Februari 2021; Published: Maret 2021

Ed: Maret 2021; 8(1): 37-48

\begin{abstract}
Abstrak
Penelitian ini bertujuan untuk meningkatkan kemampuan passing bawah dalam permainan bola voli pada siswa kelas VII di SMP Satu Atap 3 Pringgasela. Penelitian ini merupakan jenis Penelitian Tindakan Kelas (PTK) yang bertujuan untuk memeperbaiki dan meningkatkan kualitas pembelajaran serta membantu memberdayakan guru dalam memecahkan masalah pembelajaran disekolah. Desain penelitian ini menggunakan metode Massed Practice dalam 2 siklus yang terdiri dari perencanaan, pelaksanaan, pengamatan tindakan dan evaluasi/refleksi. Sampel dalam penelitian ini sebanyak 12 siswa dari kelas VII. Hasil penelitian menunjukan bahwa teknik passing bawah bola voli menggunakan metode massed practice pada siswa kelas VII di SMP Satu Atap 3 Pringgasela mengalami peningkatan yaitu dari hasil tes siklus I diperoleh 5 siswa $(41,6 \%)$ tuntas dan 7 siswa $(58,3 \%)$ belum tuntas. Kemudian pada siklus II menunjukan 9 siswa (75\%) dan 3 siswa (25\%) belum tuntas. Berdasarkan hasil tersebut dapat dikatakan terjadi peningkatan $33 \%$ pada siklus I dan siklus II.
\end{abstract}

Kata Kunci: Passing Bawah, Massed Practice.

\begin{abstract}
The following reaserch intends for intensifying volleyball lower passing skills at 1st grade students in SMP Satu Atap 3 Pringgasela. This kind of Classroom Action Reaserch (CAR) aims to fix and increase learning quality and recover teachers to solve several learning problems at school. This reaserch uses Practice Massed Method in 2 Cycles that consists a plan, implementation, action, observation, and evaluation/reflection. The samples in this reaserchis 12 students from 1 st grade. The results show that volleyball lower passusing massed practice method at 1 st grade of SMP Satu Atap 3 Pringgasela increased from cycle 1 got 5 students (41.6\%) passed and 7 students (58.3\%) unpassed. And from cycle 2 shows 9 students (75\%) passed and 3 students (25\%) unpassed. According to the result can be stated an incrase occurs 33\% in cycle 1 and 2.
\end{abstract}

Keywords: Under Passing, Massed Practice.

\section{PENDAHULUAN}

Pendidikan jasmani adalah proses interaksi sistematik antara anak didik dan lingkungan yang dikelola secara efektif dan efisien menuju pembentukan manusia seutuhnya. Pendidikan jasmani merupakan mata pelajaran yang memiliki karekteristik yang berbeda dengan pelajaran lainnya. Pendidikan jasmani merupakan pendidikan yang mengutamakan aktivitas gerak sebagai media pendidikan. Melalui aktivitas gerak diharapkan akan dapat membantu perkembangan dan pertumbuhan siswa secara keseluruhan baik fisik, mental, sosial, dan emosional (Hidayat, 2014).

Pendidikan jasmani pada siswa harus terus ditanamkan agar dapat meningkatkan perkembangan fungsi organ tubuh dan kemampuan gerak siswa. Untuk mendukung hal tersebut maka para guru selalu memberikan beberapa kegiatan diantaranya yaitu olahraga. Olahraga adalah suatu aktivitas 
yang dapat melatih tubuh. Kegiatan olahraga yang rutin dapat memiliki manfaat untuk menjaga kesehatan tubuh, salah satunya yaitu bola voli.

Bola voli adalah olahraga permainan yang dimainkan oleh dua grup berlawanan. Permainan bola voli memiliki teknik yang yang harus benar-benar di kuasai. Penguasaan teknik dasar bola voli dan sebuah kondisi fisik yang baik tidaklah mudah. Perlu latihan keras yang dimulai sejak dini. Jika teknik dasar telah dimiliki dengan baik maka akan dapat bermain bola voli dengan baik pula (Baehaqie, 2015). Menurut Winarno dan Sugiono (dalam Widiyaraya, 2016) menyatakan bahwa teknik dasar bermain bola voli dapat dibagi menjadi empat komponen teknik yaitu passing, service, smash, dan blok.

Pengamatan dalam proses pelaksanaan pembelajaran permainan bola voli di sekolah menentukan bahwa banyak masalah yaitu kurangnya penguasaan keterampilan gerak passing. Passing dalam permainan bola voli dikenal ada dua yaitu passing bawah dan passing atas, akan tetapi passing bawah yang memiliki peran yang vital tanpa mengesampingkan passing atas karena perkenaan passing bawah pada permainan bola voli frekuensinya lebih sering dilakukan (Abduh, 2016). Pembelajaran passing bawah pada siswa kelas VII di SMP Satu Atap 3 Pringgasela sering mengalami beberapa masalah, dimana hasil dari pembelajaran dinilai masih kurang maksimal. Terutama pada pembelajaran gerak dasar passing bawah yang sudah diajarkan oleh guru di sekolah.

Pembelajaran passing bawah pada siswa kelas VII di SMP Satu Atap 3 Pringgasela dapat ditingkatkan dengan melakukan gerakan latihan dengan frekuensi sebanyak-banyaknya. Latihan yang dilakukan harus sesuai dengan langkah-langkah yang benar dan tentunya diperlukan program perencanaan maupun metode yang benar pula untuk mencapai hasil yang optima. Namun, dalam usaha untuk mencapai hasil optimal tersebut banyak faktor yang mempengaruhi keberhasilan pembelajaran sehingga perlu adanya metode-metode latihan yang dilakukan, salah satunya yaitu massed practice. Latihan pembelajaran massed practice adalah pengaturan giliran latihan yang dilakukan secara terus menerus. Metode latihan massed practice merupakan cara latihan yang dilakukan secara terus menerus tanpa diselingi waktu istirahat (Anggiansyah, 2019). Latihan ini merupakan latihan yang diharapkan dapat meningkatkan belajar siswa dalam melakukan teknik passing bawah dalam permainan bola voli.

Berdasarkan uraian tersebut untuk mengetahui pengaruh metode pembelajaran massed practice pada passing bawah dalam permainan bola voli, sehingga perlu dilakukan penelitian dengan judul "Upaya Meningkatkan Hasil Belajar Passing Bawah Bola Voli dengan Pendekatan Pembelajaran Massed Practice pada Siswa Kelas VII di SMP Satu Atap 3 Pringgasela Tahun Pelajaran 2019/2020".

\section{METODE}

Penelitian ini merupakan penelitian yang menggunakan penelitian tindakan kelas (Classroom Action Research ). Penelitian Tindakan Kelas (PTK) merupakan suatu perencanaan terhadap kegiatan yang sengaja dimunculkan dan terjadi dalam sebuah kelas (Aqib, 2006). Penelitian tindakan kelas bertujuan untuk memeperbaiki dan meningkatkan kualitas pembelajaran serta membantu memberdayakan guru dalam memecahkan masalah pembelajaran disekolah.

Adapun yang menjadi populasi dalam penelitian ini adalah seluruh siswa kelas VII di SMP Satu Atap 3 Pringgasela. Dan yang menjadi sampel yang diambil dalam penelitian ini adalah keseluruhan dari siswa kelas VII yang terdiri dari 12 orang laki-laki. 
Dalam penelitian ini instrumen yang digunakan adalah :

1. Instrumen Pembelajaran

Instrumen pembelajaran yang digunakan dalam penelitian ini meliputi

a. Silabus

Silabus dibuat sebagai pedoman dalam membuat rencana pelaksanaan pembelajaran.

b. Rencana Pelaksanaan Pembelajaran (RPP)

Rencana pelaksanaan pembelajaran dibuat dan digunakan sebagai panduan penelitian untuk mengatur jalannya proses pembelajaran.

c. Lembar Observasi

Lembar observasi ini untuk mengontrol siswa dalam setiap pembelajaran yang meliputi aspek afektif, kognitif dan, psikomotor.

2. Instrumen rancangan siklus

Dalam penelitian tindakan kelas ini terdiri dari 2 siklus dan setiap siklusnya terdiri dari 4 tahap yaitu perencanaan, pelaksanaan, pengamatan tindakan dan evaluasi/refleksi. Berikut 2 siklus yang digunakan dalam penelitian ini yaitu :

a. Siklus I

1) Perencanaan

Pada tahap ini peneliti dan guru menyusun sekenario pembelajaran yang terdiri dari:

a) Tim peneliti melakukan analisis kurikulum untuk mengetahui kompetensi dasar yang akan disampaikan siswa dalam pembelajaran penjasorkes

b) Membuat RPP yang mengacu pada metode massed practice.

c) Menyiapkan media untuk membantu pengajaran

d) Menyusun alat evaluasi pembelajaran.

2) Pelaksanaan

Dalam tahap ini peneliti melaksanakan pembelajaran passing bawah bola voli dengan langkah kegiatan antara lain:

a) Menjelaskan kegiatan belajar mengajar passing bawah bola voli

b) Melakukan pemanasan

c) Membentuk kelompok/barisan

d) Melakukan latihan teknik dasar passing bawah bola voli dengan metode pembelajaran massed practice/latihan padat

e) Menarik kesimpulan

f) Penilaian langsung selama proses pembelajaran berlangsung

g) Melakukan pendinginan

3) Pengamatan tindakan

Pengamatan dilakukan terhadap:

a) Aktivitas siswa selama pembelajaran berlangsung (afektif)

b) Kemampuan melakukan rangkaian gerakan keterampilan passing bawah bola voli (psikomotor)

c) Hasil kemampuan saat melakukan passing bawah (kognitif)

4) Evaluasi/refleksi 
Instrumen evaluasi/refleksi merupakan uraian tentang prosedur analisis terhadap hasil penelitian dan refleksi terkait dengan proses dan dampak tindakan perbaikan yang dilaksanakan serta kriteria dan rencana bagi siklus tindakan berikutnya.

\section{b. Siklus II}

Pada siklus II perencanaan tindakan dikaitkan dengan hasil yang telah dicapai pada tindakan siklus I sebagai upaya perbaikan dari siklus tersebut dengan materi pembelajaran sesuai dengan silabus mata pelajaran pendidikan jasmani. Demikian juga termasuk perwujudan tahap pelaksanaan, observasi, analisis, dan refleksi yang juga mengacu pada siklus sebelumnya.

Data yang diperoleh dalam penelitian tindakan kelas ini berupa catatan tentang hasil pengamatan yang dikumpulkan melalui pengamatan (data observasi) yaitu pengamatan proses pembelajaran terhadap siswa yang bertujuan untuk mengetahui bagaimana sikap dan perilaku siswa dalam mengikuti proses pembelajaran, dan pengamatan proses pembelajaran terhadap guru yang bertujuan untuk mengetahui bagaimana guru dalam mengajar. Hasil tes siswa (tes psikomotor) yaitu dengan mengetahui hasil belajar siswa dalam penguasaan passing bawah bola voli melalui metode massed practice.

Data yang dikumpulkan pada setiap observasi dari pelaksanaan siklus PTK dianalisis secara deskriptif dengan menggunakan teknik prosentase untuk melihat kecendrungan yang terjadi dalam kegiatan pembelajaran. Dalam penelitian ini teknik yang digunakan dalam pengumpulan data yaitu berupa data-data dalam bentuk lembaran observasi seperti pengamatan proses pembelajaran terhadap siswa.

1. Analisis Data Lembar Observasi Siswa

\begin{tabular}{|c|c|c|c|c|c|}
\hline \multirow[b]{2}{*}{ No. } & \multirow[b]{2}{*}{ Aspek-aspek yang Diamati } & \multicolumn{4}{|c|}{ Skor } \\
\hline & & 4 & 3 & 2 & 1 \\
\hline 1. & $\begin{array}{l}\text { Siswa dapat bekerjasama dengan siswa lain } \\
\text { dalam menyiapkan peralatan pembelajaran }\end{array}$ & & & & \\
\hline 2. & $\begin{array}{l}\text { Siswa terlihat antusias dengan aktif mengikuti } \\
\text { pembelajaran }\end{array}$ & & & & \\
\hline 3. & $\begin{array}{l}\text { Siswa dapat bergerak aktif melakukan gerakan } \\
\text { yang telah diperintahkan }\end{array}$ & & & & \\
\hline 4. & Siswa memperoleh kesempatan bertanya & & & & \\
\hline 5. & $\begin{array}{l}\text { Siswa memenuhi dan dapat melakukan } \\
\text { permainan yang diberikan }\end{array}$ & & & & \\
\hline 6. & $\begin{array}{l}\text { Seluruh siswa dapat bekerja sama dalam } \\
\text { melakukan permainan }\end{array}$ & & & & \\
\hline 7. & $\begin{array}{l}\text { Siswa melakukan pemanasan dengan sungguh- } \\
\text { sungguh }\end{array}$ & & & & \\
\hline 8. & $\begin{array}{l}\text { Siswa dapat menggunakan alat pembelajaran } \\
\text { secara efektif }\end{array}$ & & & & \\
\hline 9. & $\begin{array}{l}\text { Siswa dapat melakukan evaluasi yang diberikan } \\
\text { oleh guru }\end{array}$ & & & & \\
\hline 10. & $\begin{array}{l}\text { Siswa melakukan passing bawah dengan } \\
\text { sungguh-sungguh }\end{array}$ & & & & \\
\hline 11. & $\begin{array}{l}\text { Siswa dapat melakukan tahap passing bawah } \\
\text { bola voli }\end{array}$ & & & & \\
\hline 12. & $\begin{array}{l}\text { Siswa tidak takut tidak ragu dalam melakukan } \\
\text { passing bawah }\end{array}$ & & & & \\
\hline 13. & $\begin{array}{l}\text { Siswa melakukan pendinginan dengan sungguh- } \\
\text { sungguh }\end{array}$ & & & & \\
\hline & Jumlah & & & & \\
\hline & Total skor & & & & TT1 \\
\hline
\end{tabular}


Keterangan

Berilah tanda centang (v) pada kolom yang sudah disediakan sesuai dengan kriteria sebagai berikut:

a. Kriteria penilaian skor

1) Skor 4 Sangat Baik (SB): jika siswa selalu melakukan

2) Skor 3 Baik (B) : jika siswa sering melakukan

3) Skor 2 Cukup Baik (CB): jika siswa kadang-kadang melakukan

4) Skor 1 Tidak Baik (TB) : jika siswa tidak pernah melakukan

b. Kriteria pendekatan jumlah skor

1) Skor $13-25$ : pelaksanaan pembelajaran berjalan kurang baik

2) Skor 26-38: pelaksanaan pembelajaran cukup baik

3) Skor $39-52$ : pelaksanaan pembelajaran dengan baik

2. Analisis Data Lembar Observasi untuk Guru

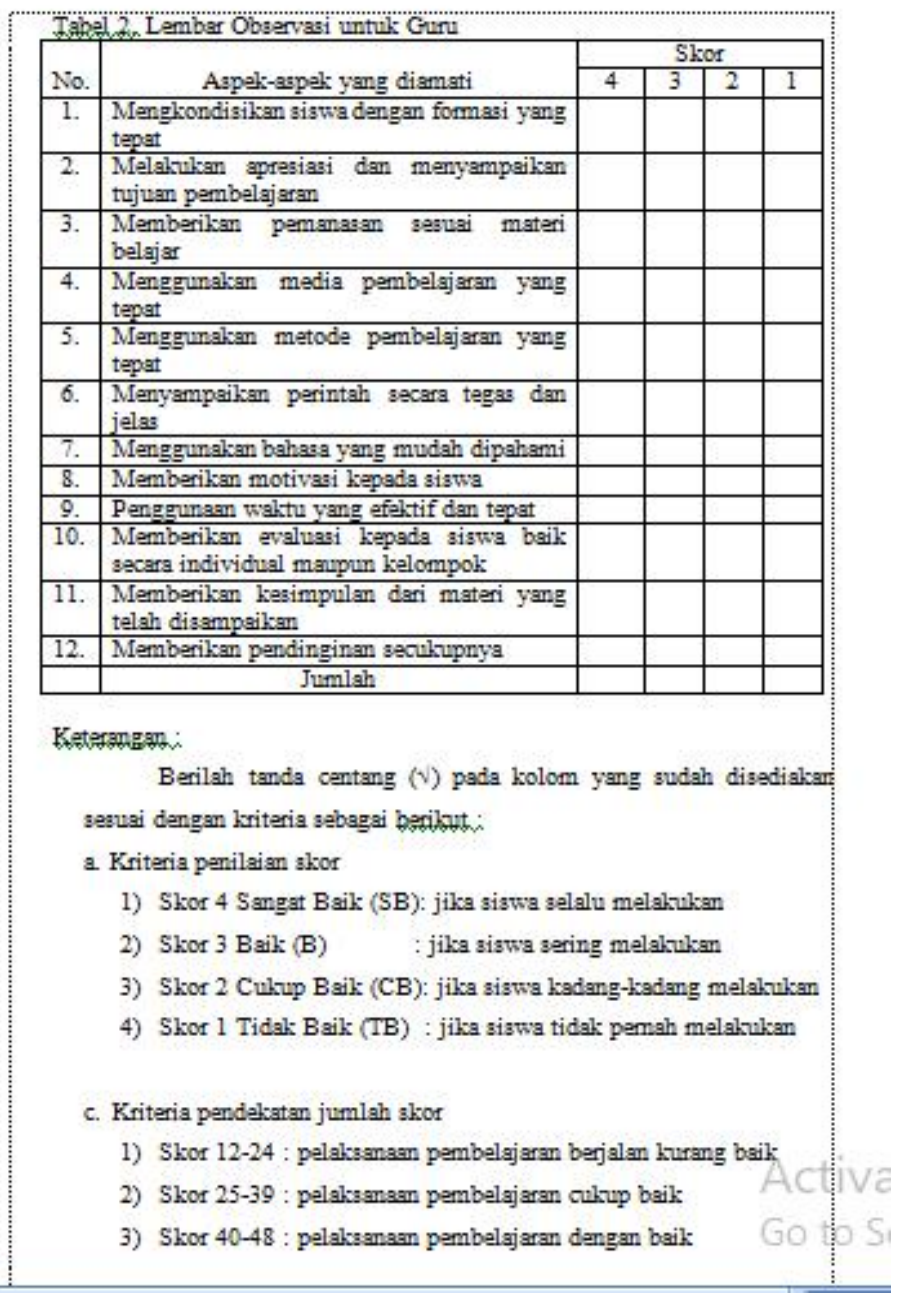


3. Analisis Data Hasil Belajar Siswa

a. Tes Passing Bawah 60 Detik

Tabel 3. Nilai Tes Passing Bawah
\begin{tabular}{|c|c|c|c|}
\hline \multirow{2}{*}{ No. Hasil } & \multirow{2}{*}{ Nilai } \\
\cline { 2 - 3 } & Putra & Putri & 5 \\
\hline 1. & $47<\mathrm{X}$ & $45<\mathrm{X}$ & 4 \\
\hline 2. & $40-46$ & $37-44$ & 3 \\
\hline 3. & $27-39$ & $21-36$ & 2 \\
\hline 4. & $17-26$ & $13-20$ & 1 \\
\hline 5. & $\mathrm{X}<16$ & $\mathrm{X}<12$ & \\
\hline
\end{tabular}

Perhitungan:

$$
\text { Nilai }=\frac{\text { jumlah skor yang diperoleh }}{\text { total skor }} \times 100
$$

b. Penilaian Teknik Passing Bawah

Tabel 4 Penilaian Pengamatan pada Teknik Passing Bawah

\begin{tabular}{|c|c|c|c|c|c|c|}
\hline \multirow[b]{2}{*}{ No. } & \multirow[b]{2}{*}{ Teknik Passing Bawah } & \multicolumn{5}{|c|}{ Skor } \\
\hline & & 1 & 2 & 3 & 4 & 5 \\
\hline 1. & Persiapan & & & & & \\
\hline 2. & Pelaksanaan Gerak & & & & & \\
\hline 3. & Gerak Lanjutan & & & & & \\
\hline & Jumlah skor & & & & & \\
\hline
\end{tabular}

Keterangan : Berilah tanda $(\sqrt{ })$ pada setiap kualitas jawaban

Skor 1-5 jika memenuhi beberapa diantara masing-masing teknik passing bawah yang telah ditentukan yaitu:

1) Skor 1 : siswa sudah melakukan salah satu teknik dengan baik

2) Skor 2 : siswa sudah melakukan dua diantara beberapa teknik yang ada dengan baik

3) Skor 3 : siswa sudah melakukan tiga diantara beberapa teknik yang ada dengan baik

4) Skor 4 : siswa sudah melakukan empat diantara beberapa teknik yang ada dengan baik

5) Skor 5 : siswa sudah melakukan semua (lima) diantara beberapa teknik yang ada dengan baik

Adapun teknik-teknik passing bawah tersebut antara lain :

1) Persiapan

a) Bentuk landasan dengan lengan

b) Sikut terkunci

c) Tekuk lutut, tahan dalam posisi rendah

d) Kaki dalam posisi meregang selebar bahu

e) Bergerak ke arah datangnya bola dan atur posisi tubuh

2) Pelaksanaan Gerak 
a) Terima bola pada landasan di depan badan

b) Kaki sedikit diundurkan

c) Berat badan dialihkan ke depan

d) Pukul bola jauh dari badan

e) Perkenaan pada lengan bagian dalam pada permukaan yang halus diantara pergelangan tangan dan siku

3) Gerak Lanjutan

a) Jari tangan tetap digenggan

b) Siku tetap terkunci

c) Landasan mengikuti bola ke sasaran

d) Pindahkan berat badan ke arah sasaran

e) Perhatikan bola bergerak ke sasaran

Perhitungan :

Nilai $=\frac{\text { jumlah skor yang diperoleh }}{\text { total skor }} \times 100$

c. Analisis Hasil Belajar Siswa

1) Rumusan nilai akhir passing bawah

Nilai Akhir $=\frac{\text { Tes } 60 \text { detik }+ \text { teknik passing bawah }}{2}$

2) Persentase penguasaan kegiatan secara klasikal

Ketuntasan Klasikal $=\frac{\text { Jumlah subjek berhasil }}{\text { Jumlah subjek keseluruhan }} \times 100$

d. Analisis Hasil Belajar Aspek Kognitif Siswa 
Tabel 5. Hasil Belajar Aspek Kognitif Siswa

\begin{tabular}{|lr|l|}
\hline 1. Konsep & keterampilan & Menjelaskan sikap awal passing \\
gerak & fundamental & bawah bola voli dengan benar \\
\cline { 3 - 3 } & bola volli & Menjelaskan sikap perkenaan \\
& bola pada passing bawah bola \\
& voli dengan benar. \\
\cline { 3 - 4 } & Menjelaskan sikap akhir pasing \\
& bawah bola voli dengan benar. \\
\hline
\end{tabular}

Perhitungan:

$$
\text { Nilai }=\frac{\text { skor yang diperoleh }}{2} \times 100
$$

\section{HASIL DAN PEMBAHASAN}

\section{Pra Siklus}

Dari hasil pra-siklus didapat rata-rata aktivitas persentase kemampuan siswa yaitu $40 \%$. Hasil tersebut menunjukkan bahwa nilai rata-rata kemampuan siswa belum mencapai nilai indikator keberhasilan penelitian yaitu 70\%. Hal ini dikarenakan pengetahuan siswa mengenai teknik dasar bola voli masih kurang dan belum dipelajari dengan baik. Sehingga perlu adanya peningkatan dalam pembelajaran khususnya pada teknik dasar passing bawah bola voli.

\section{Siklus I}

Siklus I mulai dilakukan pada hari rabu, 4 maret 2020. Terdapat empat langkah pada siklus ini yaitu perencanaan, pelaksanaan, pengamatan tindakan, dan evaluasi/ refleksi. Pada pertemuan ke 2, observasi mengajar yang didapat oleh peneliti yaitu: pada observasi guru 58,33\% dan pada siswa 51,92\%. Berdasarkan penjelasan dari hasil lembar observasi guru dan siswa pada siklus 1 di atas, disimpulkan bahwa kualitas pembelajaran passing bawah belum mencapai indikator keberhasilan dalam penelitian ini.

Berdasarkan penelitian pada siklus I, didapat hasil kemampuan passing bawah bola voli berpasangan siswa/i kelas VII SMP Satu Atap 3 Pringgasela menunjukkan bahwa kemampuan siswa masih dikategorikan rendah. Setelah melakukan analisis pada siklus I, sudah ada peningkatan antara siklus I dengan pra-siklus. Pada siklus I ini persentase kemampuan siswa sudah meningkat dibandingkan dengan pra-siklus, tetapi peningkatannya belum mencapai indikator keberhasilan yaitu $70 \%$. Adapun hasil analisis passing bawah bola voli metode massed practice dapat dilihat pada tabel 6. 


\section{Tabel 6. Hasil Analisis Passing Bawall Bola Voli Metode Massed Practice Siklus I

\begin{tabular}{|l|l|l|l|l|}
\hline No. & Skor & Frekuensi & Persentase (\%) & Keterangan \\
\hline 1. & $73 \leq X$ & 5 & 41,6 & Tuntas \\
\hline 2. & $\mathrm{X} \geq 73$ & 7 & 58,3 & Belum Tuntas \\
\hline
\end{tabular}

Berdasarkan hasil penelitian siklus I bahwa 5 siswa atau 41,6 \% siswa sudah tuntas namun 7 siswa atau 58,3\% siswa belum tuntas. Data tersebut belum mencapai indikator keberhasilan yaitu 70\%. Dari hasil tersebut maka dilakukan penelitian untuk siklus II. Untuk memperjelas hasil analisis passing bawah bola voli metode massed practice siklus I dapat dilihat pada gambar 1 .

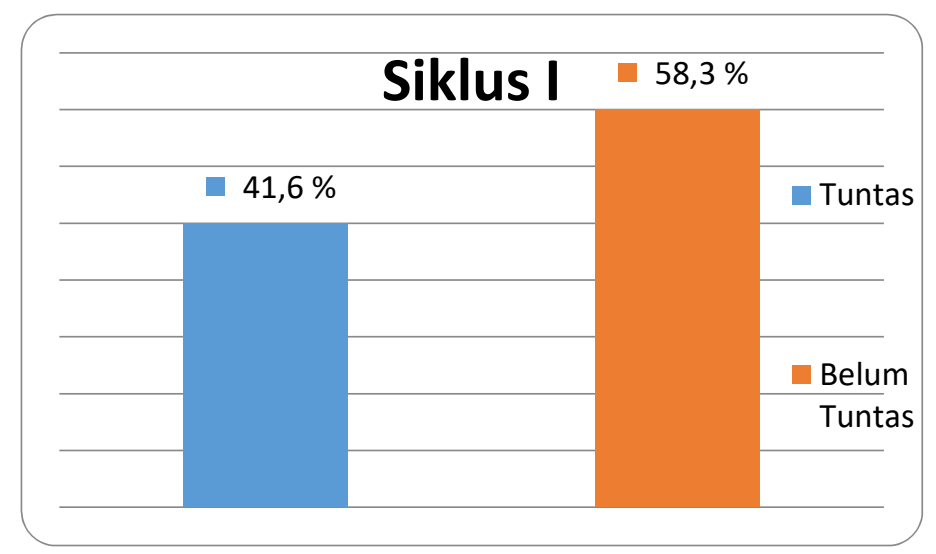

Gambar 1. Grafik Hasil Analisis Siklus I

\section{Siklus II}

Berdasarkan penelitian pada siklus I, didapat hasil kemampuan passing bawah berpasangan siswa/i kelas VIII SMP Satu Atap 3 Pringgasela menunjukkan bahwa kemampuan siswa sudah ada peningkatan antara siklus II dengan siklus I. Pada siklus II ini persentase kemampuan siswa sudah meningkat dibandingkan dengan siklus I yaitu sebesar $75 \%$. Adapun hasil analisis Passing bawah bola voli metode massed practice dapat dilihat pada tabel 7.

Tabel 7. Hasil Analisis Passing Bawah Bola Voli Metode Massed Practice Siklus II

\begin{tabular}{|l|l|l|l|l|}
\hline No. & Skor & Frekuensi & Persentase (\%) & Keterangan \\
\hline 1. & $73 \leq \mathrm{X}$ & 9 & 75 & Tuntas \\
\hline 2. & $\mathrm{X} \geq 73$ & 3 & 25 & Belum Tuntas \\
\hline
\end{tabular}

Berdasarkan dari hasil penelitian bahwa 9 siswa atau $75 \%$ siswa sudah tuntas dalam melakukan passing bawah dengan metode massed practice dan 3 siswa atau $25 \%$ siswa belum tuntas. untuk lebih jelasnya mengenai hasil analisis passing bawah metode massed practice siklus II dapat dilihat pada gambar 2 . 


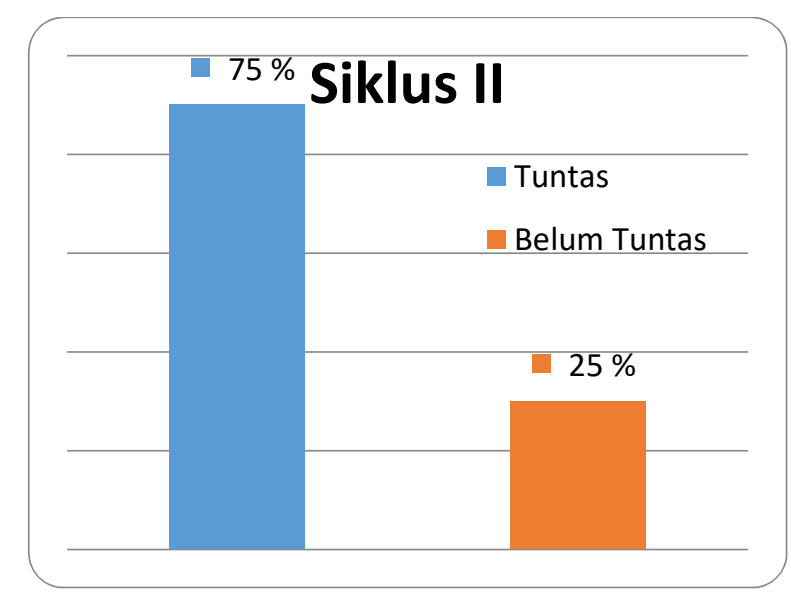

Gambar 2. Grafik Hasil Analisis Siklus II

Berdasarkan Gambar 6. dan Tabel 7. menandakan bahwa hasil analisis passing bawah bola voli metode massed practice sudah memenuhi kategori keberhasilan yaitu $70 \%$ dan dari data tersebut dapat dilihat bahwa sudah adanya peningkatan pada passing bawah bola voli metode massed practice pada siklus II. Adapun perbandingan antara siklus I dan siklus II dapat dilihat pada tabel 8 .

Tabel 8. Perbandingan Tingkat Ketuntasan Belajar Passing Bawah Bola Voli Metode Massed Practice Pada Siklus I dan Siklus II

\begin{tabular}{|l|l|l|}
\hline Siklus & Tuntas & Belum Tuntas \\
\hline I & 5 & 7 \\
\hline II & 9 & 3 \\
\hline
\end{tabular}

Berdasarkan tabel 8. dapat diketahui bahwa pada siklus II sudah mengalami peningkatan sebesar 33\% dibandingkan dengan siklus I. Dari data tersebut sudah membuktikan bahwa siswa sudah mengalami peningkatan sehingga tidak perlu ada tindakan lanjutan untuk meningkatkan persentasi pembelajaran pada siswa. Untuk memperjelah perbandingan antara siklus I dan siklus II dapat dilihat pada gambar 3.

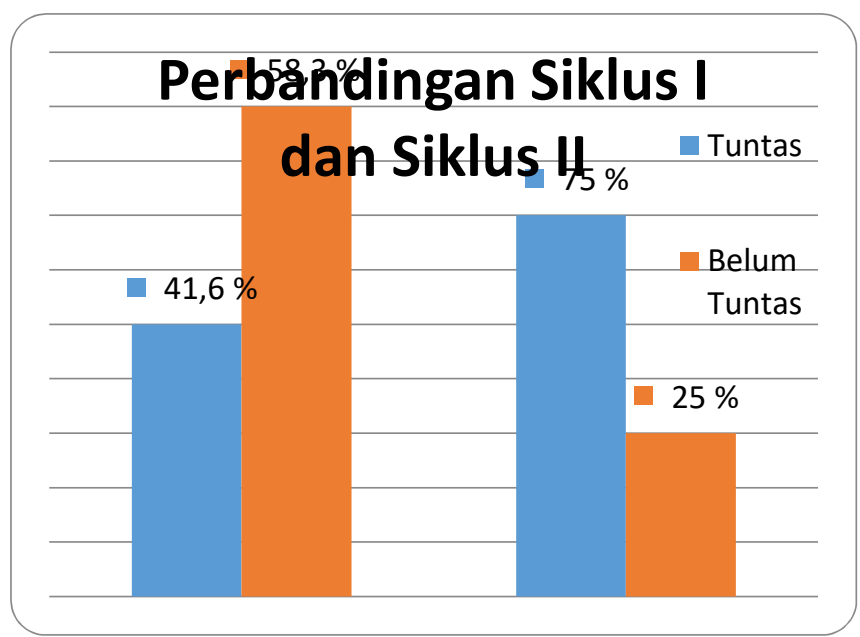

Gambar 3. Grafik Perbandingan Siklus I dan Siklus II 


\section{PEMBAHASAN}

Penelitian Tindakan Kelas di SMP Satu Atap 3 Pringgasela meliputi 2 siklus yang terdiri dari siklus I dan siklus II. Setiap siklus terdiri dari beberapa tahapan yaitu, tahapan perencanaan, pelaksanaan, pengamatan tindakan dan evaluasi/refleksi. Pada siklus II tahapa yang dilakukan merupakan perbaikan pada siklus sebelumnya. Pada penelitian ini hasil dari kedua siklus digunakan untuk mengetahui adanya peningkatan dalam ketuntasan belajar siswa dengan melakukan passing bawah bola voli dengan metode massed practice.

Berdasarkan hasil penelitian yang telah dilakukan memiliki hasil yang meningkat. Dilihat dari hasil penelitian pada siklus I yaitu 5 siswa $(41,6 \%)$ tuntas dan 7 siswa $(58,3 \%)$ belum tuntas sedangkan pada siklus II yaitu 9 siswa (75\%) tuntas dan 3 siswa (25\%) belum tuntas. Dari hasil tersebut dapat dilihat bahwa ada peningkatan siswa yang telah tuntas dalam melakukan passing bawah. Hasil peningkatan dari siklus I dan siklus II yaitu sebesar 33\%. Hal ini dikarenakan metode latihan massed practice mempunyai pengaruh yang baik terhadap peningkatan keterampilan passing bawah dan metode ini menuntut pengulangan secara terus menerus. Dengan melakukan pengulangan secara terus menerus, maka siswa akan lebih peka dan mampu merasakan passing bawah yang dilakukan. Selain itu, metode massed practice juga mempengaruhi memori jangka panjang, dimana keterampilan yang dilakukan secara terus menerus akan tersimpan di dalam memori lebih lama, sehingga siswa akan memiliki konsep gerakan yang konsisten.

Peningkatan hasil belajar pada penelitian ini juga dipengaruhi oleh adanya kesadaran siswa tentang pentingnya penguasaan teknik dasar. Hal ini dikarenakan bahwa teknik dasar merupakan teknik yang memiliki ketentuan tertentu agar dapat melakukan keterampilan yang baik. Menurut Amung Ma'mun dan Yudha (dalam Prastiyo 2015) pencapaian suatu keterampialn dipengaruhi oleh banyak faktor. Faktor tersebut dibedakan menjadi tiga hal yaitu, (1) faktor pribadi, (2) faktor proses belajar mengajar dan (3) faktor situasional (lingkungan). Berdasarkan pendapat tersebut kegiatan belajar mengajar harus diciptakan suasana yang baik agar guru dapat menyampaikan materi dengan mudah dan dapat diterima oleh siswa. Selain agar mudah diterima oleh siswa, guru harus mampu menyampaikan materi dengan tahapan yang mudah disesuaikan dengan kemampuan yang dimiliki siswa. Hal ini dikarenakan setiap siswa memiliki karakter dan tingkat keterampilan yang berbeda-beda sehingga harus mampu memberikan pembelajaran yang disesuaikan dengan kemampuan secara klasikal.

\section{KESIMPULAN}

Berdasarkan hasil penelitian dan pembahasan dapat disimpulkan bahwa penggunaan metode massed practice pada teknik dasar passing bawah di SMP Satu Atap 3 Pringgasela mengalami peningkatan. Peningkatan hasil belajar tersebut dapat dilihat dari adanya peningkatan dari siklus I dan siklus II sebesar $33 \%$. Hasil tersebut didapat dari penelitian pada siklus I bahwa 5 siswa $(41,6 \%)$ tuntas dan 7 siswa $(58,3 \%)$ belum tuntas. Sedangkan pada siklus II bahwa 9 siswa $(75 \%)$ tuntas dan 3 siswa $(25 \%)$ belum tuntas.

Berdasarkan kesimpulan hasil penelitian mengenai peningkatan teknik passing bawah bola voli dengan metode massed practice pada siswa SMP Satu Atap 3 Pringgasela, maka penulis dapat menyampaikan beberapa saran yang nantinya dapat dijadikan masukan atau sebagai bahan pertimbangan. Adapun saran dalam penelitian ini yaitu :

1. Perlu dilakukan penelitian dengan menggunakan metode pembelajaran dengan beberapa modifikasi yang lebih beragam dalam setiap materi agar pembelajaran dapat berjalan dengan baik. 
2. Perlu adanya penelitian lanjutan mengenai sarana dan prasarana yang terdapat pada sekolah.

3. Penelitian selanjutnya sangat direkomendasikan guna menemukan teknik

4. yang dapat diaplikasikan dalam pembelajaran..

\section{DAFTAR PUSTAKA}

Abduh, I. 2016. Peningkatan Pembelajaran Passing Bawah dalam Permainan Bola Voli melalui Model Pembelajaran Langsung (Direct Instructions) pada Siswa Kelas V SDN No 1 Pesaku Kecamatan Dolo Barat Kabupaten Sigi. E-jurnal Physical Education, Healt and Recreation 04(01) : 2337- 4535.

Anggiansyah, J. 2019. Pengaruh Metode Latihan Massed Practice, Distributed Practice dan Koordinasi Mata-Kaki Terhadap Ketepatan Shooting ke Gawang dalam Permainan Sepakbola pada Siswa Usia 14 Tahun SSB Gama Yogyakarta Tahun 2018. Skripsi. Fakultas Ilmu Keolahragaan Universitas Negeri Yogyakarta.Yogyakarta.

Hidayat, T. 2014. Perbandingan Metode Massed Practice Dan Distributed Practice terhadap Hasil Belajar Sepak Sila (Studi pada Siswa Kelas V SDN Sambikerep 2 Surabaya). Jurnal Pendidikan Olahraga dan Kesehatan 2(2):436 - 443.

Widiyaraya, A.A, A. Tomi, dan Sulistyorini. 2016. Meningkatkan Keterampilan Passing Bawah Menggunakan Latihan Bervariasi pada Siswa Peserta Ekstrakurikuler Bolavoli SMK Negeri 2 Singosari Kabpaten Malang. Pendidikan Jasmani. 